\title{
Application and Adaptation of Traditional Elements in Environmental Art Design
}

\author{
$\mathrm{Li} \mathrm{Li}$ \\ Jiangxi Institute of Fashion Technology
}

Keywords: Traditional elements; Environmental art design; Application; Adaptation

\begin{abstract}
With the development of economy and society, people begin to pursue design philosophy and cultural connotation. Although era is developing, traditional factors are still favored and thus they are added into environmental art design. Forming an ingenious combination with environmental design, traditional elements play an unique role in environmental art design. Even Chinese traditional elements are involved in western designs. This text is to set forth the combination of traditional elements and environmental art design from two aspects, i.e., application and adaptation of traditional elements in environmental art design.
\end{abstract}

\section{Introduction}

Following the development of modern environmental art, the concept of environmental art design enjoys popular support. The scope of environmental art design is quite broad. Current environmental art design is not only simple design of park and garden construction and design of home furnishing decoration, but also it is connected to many fields such as design psychology and materialogy. People selectively add traditional elements into environmental art design. Traditional elements have their own features. Environmental art design is also affected by the environment so that it replies more on traditional elements. Moreover, traditional elements bring environmental art design freshness, a sensory enjoyment. Designs on the background of Chinese traditional elements give people a kind of beautiful enjoyment. However, several adaptation problems occur in the application process of designs.

\section{Concept of Traditional Elements}

Traditional elements are exactly unique features in Chinese traditional culture. How lofty and great the 5000-year history of Chinese culture is. Over the long history, Chinese traditional culture is depositing continually. At present, Chinese traditional culture that could be inherited and promoted by us is absolutely excellent. The opening of Confucianism definitely creates a breakthrough in the history of traditional elements. Confucianism still has warning function to some extent nowadays.

Chinese civilization has a history of five thousand years. For five thousand years, traditional culture elements are all-embracing. Excellent cultural elements such as Chinese Oracle bone script, typography, Chinese painting, Chinese porcelain, Chinese tea art, the "scholar's four jewels", Chinese tunic suit, chopsticks and Chinese knot are eulogized all the time. Both small elements and large elements are intangible cultural heritages left to us from Chinese traditional culture. Not merely do those excellent traditional cultures bring elements with symbolic significance. The majority of Chinese people think that whatever embody the spirit of Chinese traditional culture and features of Chinese long history are Chinese traditional elements.

\section{Application of Traditional Elements in Environmental Art Design}

Environmental art design includes two aspects, interior design and exterior design. The former is mainly home design and the later mainly includes urban greening design, garden design and landscape design. Designers use another mode to present these excellent traditional cultural elements, for example, three-dimensional elements become plane ones. Designers use the form or character or 
pattern to embed traditional elements into environmental art design. Sometimes, not only one traditional element is selected for basic design but many traditional elements are used to form a perfect combination. Traditional elements play a role in environmental art design, conveying some kinds of messages. Chinese traditional culture is extensive and profound. Countless traditional elements give designers infinite inspiration of creation. At the back of five thousand years of civilization, traditional elements' participation in environmental art design not only gives people visual beauty in design but also is of great benefit to the promotion and inheritance of the traditional culture of Chinese nation. After all, how are traditional elements applied in environmental art design?

Chinese calligraphy and Chinese painting hung on the wall of room are both edifying fruits of traditional culture. Ru-Yi Pattern and auspicious clouds engraved on the door frame and window imply good luck and happiness. The concept of good luck and happiness is the sincerest greeting words for Chinese people. Not only patterns of auspicious clouds are engraved but also many trees on both sides of the street are trimmed to the graphic pattern of auspicious clouds in afforestation of city. Not only every family but also the whole city is safe. Being applied everywhere, Chinese knot is knitted with merely one rope from beginning to end, glowing red. Different shapes of Chinese knots have different symbolic meanings. Many people hang Chinese knots in their cars. What's more, many people hang Chinese knots in their rooms at Chinese New Year to increase the atmosphere of celebrating the festival. Stone lion is the representative of safety guard for Chinese people. Stone lions are frequently found at the gates of many places of interest. Moreover, government chooses to place stone lions at the gate because they symbolize solemnity and force. Two stone lions are placed on both left and right sides in bilateral symmetry, one male and one female. Just like guardian angel, stone lion is the symbol of safety and luck, conveying the meaning of pursuing beautiful prospect. Nowadays, many people choose Chinese embroidery to enrich the life after work or in spare time. Embroidery is a traditional handicraft in China and it can be classified into many categories, among which cross-stitch is one kind of embroidery. Cross-stitch has found a wide application. Its embroidery technique is quite simple. Cross-stitch is generally used to embroider landscapes and so on. Decorations in clocks and watches, and hanging decorations are cross-stitch works. When crossstitch is applied in decoration, each work of different styles of cross-stitch implies a distinct meaning. For example, pattern of fine horse emblems making rapid advances in one's career, pattern of blooming flowers emblems wealth and honor, and pattern of rising sun emblems another meaning. Many people give embroidery works finished in spare time to their friends as gifts. China is the hometown of porcelain whose history can be traced back to a long time ago. China had already had porcelain in about 16th century B.C. Moreover, porcelain has another name, China, the same name as English expression of Chinese country. It goes no denying that China is very important in Chinese traditional culture. The relationship between China and environmental art design is very close. There is a wide selection and application for China in interior design. Generally China is used to make a vase or flowerpot. What's more, patterns of peony, plum blossoms, orchid, bamboo and chrysanthemum, dragon design, auspicious clouds and jade sceptre are easily found in China, which is the expression of traditional elements in China and also the embodiment of traditional elements in environmental art design.

"Auspicious Clouds" torch in the 2008 Olympic Games is the best expression of traditional elements in environmental art design. The design of decorated archway in the Olympic Village is the detailed demonstration of Chinese classicism. Picture scroll, Analects of Confucius, movable-type printing and the Great Wall appearing in the opening ceremony of Beijing Olympic Games all belong to Chinese traditional culture. The addition of traditional elements make foreign people better understand and comprehend the Chinese culture. Traditional elements applied in the design philosophy of the 2008 Olympic Games all reflect the perfect combination of traditional elements and environmental art design.

People's aesthetic standard is developing continuously with social development. People pursue design aesthesia. At the same time, they go after the beauty of traditional culture. Beautiful visual perception expressed by traditional elements in environmental art design is irreplaceable. Generally it is required that environmental art design should embody characteristics, considering mentality and visual perception of everyone. Cultural characteristics reflected by traditional elements are of long 
standing. Chinese designs have got affected by western designs so that many people gradually choose western designs. As a result, the status of traditional elements in environmental art design is threatened. For Chinese people, traditional elements not only mean beautiful visual perception but also a sense of honor. Traditional elements appearing in environmental art design are definitely in conformity to current aesthetical standard. It is acceptable to introduce western elements. However, in no way can we abandon traditional elements because they are our national features in any case.

\section{Adaptation of Traditional Elements in Environmental Art Design}

Although design is the emphasis of environmental art design, a good design should embody cultural features and regard cultural features as the supporting point. Many people want to feel and enjoy the cultural connotation of each design. A design with rich cultural connotations occupies an important place in the heart of people. With the development of society and improvement of economy, people are more eager to pursue spiritual fulfillment. People also seek design philosophy and cultural connotation of each design besides enjoying visual beauty.

The combination of traditional elements and environmental art design promotes the development of both two sides. Affected by traditional elements, environmental art design meets people's pursuit of cultural connotation and design philosophy and also satisfies their consumption idea, facilitating the development of economy and environmental art design. Competition among countries is fierce in current society. Chinese traditional elements will promote China's cultural image. Environmental art design with traditional elements improves the status of traditional elements in environmental art design accordingly. Chinese cultural connotation is very rich. Moreover, each cultural development brings about various traditional elements and each of them conveys much design inspiration. Affected by traditional elements, environmental art designs become rich and colorful. Traditional elements have carved out a development road for environmental art design.

Environmental art design delivers traditional elements to the people. In the meantime, it transmits Chinese traditional culture to poets. It is absolutely impossible for us to let excellent cultures disappear in a big country with a population of 1.3 billion. We must inherit and promote our excellent cultures. By applying traditional elements in environmental art design, we try to present our excellent cultures to the common people so that our confidence in national culture gets promoted. In addition, environmental art design has carved out a way for the development of traditional culture in China and even the whole world.

\section{Conclusion}

The combination of Chinese traditional elements and environmental art design is very ingenious. By this way, esthetic appreciation is expressed by environmental art design and cultural connotation gets enriched. What's more, development road for traditional elements and traditional culture becomes wide and broad. Thus, Chinese traditional elements and environmental art design get mutual development. The addition of traditional elements is able to develop and expand five thousand years of civilization history for our country in the society under modernization construction. The combination of Chinese traditional elements and environmental art design is perfect and also necessary.

\section{References}

[1] Chen Zhuohao. Discussion on the Application of Traditional Elements in Modern Environmental Art Design[J]. Daguan Weekly, 2012, (50): 36-36.

[2] Li Huilin. Discussion on the Application of Chinese Traditional Decorative Elements in Modern Environmental Art Design[J]. Charming China, 2014, (1): 110-110. 
[3] Xu He. Application of Traditional Architectural Elements in Environmental Art Design[J]. Journal of Fujian Commercial College, 2013, (6): 91-94. DOI: 10.3969/j.issn.10084940.2013.06.019.

[4] Li Qin. Discussion on Application of Chinese Elements in Environmental Art Design[J]. Journal of Karamay, 2010, (3): 271-271.

[5] Wang Lan. Investigation into Function and Adaptability of Traditional Elements in Environmental Art Design[J]. Modern Decoration: Theory, 2014, (7).

[6] Li Guangwen. Traditional modeling elements in environmental art applied research [D]. Chongqing university, 2010.

[7] He Bozhi. Chinese traditional elements in the environmental art design penetration and reflect [J]. Journal of intelligence, 2012, 11:229-230.

[8] Qian Wancheng. Analyses the application of traditional Chinese elements in environmental art design [J]. Journal of movie review, 2012, 21:104-105.

[9] Sun Xiaoyi. Theory of Chinese traditional culture elements in the art design of innovative applications [D]. Jilin university, 2006.

[10] Fang Jing. Traditional dwellings decoration application in the modern environmental art design research [D]. Kunming university of science and technology, 2006.

[11] Yuan Lang. Analyses the application of traditional Chinese elements in modern environmental art design [J]. Journal of popular literature and art, cutflower production potentials of 2010:157158.

[12] Liu Fei. Folk decorative elements application in the modern environment [D]. Jingdezhen ceramic institute, 2013.

[13] Zhao Kun. Minority architectural elements in the modern environmental art design to explore the application [D]. Kunming university of science and technology, 2013.

[14] Li Dongjuan. Innovation in the design of Chinese style element in the modern environment using [D]. The northeast normal university, 2008.

[15] Zhang Xiao. The fusion of modern and traditional [D]. Hebei normal university, 2014.

[16] ShenLu. Traditional art elements in the application of cultural industrial park of visual communication design [D]. Hefei university of technology, 2014.

[17] LuoQiong. The application of traditional culture elements in modern landscape design research [D]. Anhui engineering university, 2012. 